$$
\operatorname{Conf}-950 / 10--5
$$

WHC-SA-2489-FP

\title{
Radioisotope Thermoelectric Generator Package O-Ring Seal Material Validation Testing
}

Prepared for the U.S. Department of Energy Office of Environmental Restoration and Waste Management

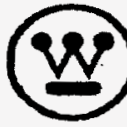

Hanford Operations and Engineering Contractor for the

U.S. Department of Energy under Contract DE-AC06-87RL10930

Copyright License $B y$ acceptance of this anticle, the publisher and/or recipient acknowledges the

U.S. Government's right to retain a nonexclusive, royalty-free license in and to any copyright covering this paper.

Approved for Public Release 
LEGAL DISCLAIMER

This report was prepared as an account of work sponsored by an agency of the United States Government. Neither the United States Government nor any agency thereof, nor any of their employees, nor any of their contractors, subcontractors or their employees, makes any warranty, express or implied, or assumes any legal liability or responsibility for the accuracy, completeness, or any third party's use or the results of such use of any information, apparatus, product, or process disclosed, or represents that its use would not infringe privately owned rights. Reference herein to any specific commercial product, process, or service by trade name, trademark, manufacturer, or otherwise, does not necessarily constitute or imply its endorsement, recommendation, or favoring by the United States Government or any agency there of or its contractors or subcontractors. The views and opinions of authors expressed herein do not necessarily state or reflect those of the United States Government or anv agency thereof.

This report has been reproduced from the best available copv.

Printed in the United States of America

DISCLM-2.CHP (1-91) 


\section{DISCLAIMER}

Portions of this document may be illegible in electronic image products. Images are produced from the best available original document. 


\title{
RADIOISOTOPE THERMOELECTRIC GENERATOR PACKAGE O-RING SEAL MATERIAL VALIDATION TESTING
}

\author{
Harold E. Adkins, Patrick C. Ferrell, and Ronald C. Knight \\ Westinghouse Hanford Company \\ P.O. Box 1970, MSIN N1-25 \\ Richland WA 99352 \\ (509) 376-2784
}

CAMERA READY MANUSCRIPT prepared for:

Twelfth Symposium

on Space Nuclear Power and Propulsion

Albuquerque, New Mexico

8-12 January 1995

initial submission:

final submission: 30 September 1994

Author to whom correspondence should be sent: Harold E. Adkins

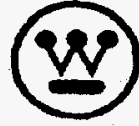

\section{Westinghouse \\ Hanford Company Richland, Washington}

Hanford Operations and Engineering Contractor lor the

U.S. Department of Energv under Contract DE-ACO6-87RL 10930

Copyright License By acceptance of this article, the publisher and/or recipient acknowledges the U.S. Government's right to retain a nonexclusive, royalty-free license in and to any copyright covering this paper.

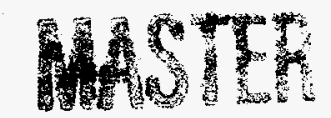

S... 


\title{
RADIOISOTOPE THERMOELECTRIC GENERATOR PACKAGE O-RING SEAL MATERIAL VALIDATION TESTING
}

\author{
Harold E. Adkins, Patrick C. Ferrell, and Ronald C. Knight \\ Westinghouse Hanford Company \\ P.O. Box 1970, MSIN N1-25 \\ Richland WA 99352 \\ (509) $376-2784$
}

\begin{abstract}
The Radioisotope Thermoelectric Generator Package O-Ring Seal Material Validation Test was conducted to validate the use of the Butyl material as a primary seal throughout the required temperature range. Three tests were performed at (1) $233 \mathrm{~K}\left(-40^{\circ} \mathrm{F}\right)$, (2) a specified operating temperature, and (3) $244 \mathrm{~K}\left(-20^{\circ} \mathrm{F}\right)$ before returning to room temperature. Helium leak tests were performed at each test point to determine seal performance. The two major test objectives were to establish that butyl rubber material would maintain its integrity under various conditions and within specified parameters and to evaluate changes in material properties.
\end{abstract}

\section{INTRODUCTION}

The Radioisotope Thermoelectric Generator (RTG) packaging uses elastomeric O-rings for the primary containment boundary seals. The elastomer chosen for the RTG packaging is butyl rubber material procured through the Rainier Rubber Company located in Seattle, Washington. The Rainier Rubber Company designation for this material is RR0405-70.

The RR0405-70 material was tested extensively to develop a time/temperature operating envelope for use in the TRUPACT-II packaging. TRUPACT-II packaging is certified to be in compliance with the Code of Federal Regulations (10 CFR 71). The seal material in the RTG packaging is subjected to time/temperature conditions outside those tested for defining the TRUPACT-II operating envelope (WHC 1989a). This does not mean that the material is unacceptable for use in the RTG packaging, but that it must be test validated as acceptable for the operational time/temperature envelope of the RTG packaging conditions.

\section{PURPOSE}

This test was performed to validate an expanded time/temperature operating envelope of the RR0405-70 butyl rubber material (WHC 1993, 1994). This expanded envelope contains the predicted time/temperature conditions for the RTG packaging, including a margin of safety.

\section{TEST PARAMETERS}

The primary interest is in the ability of the elastomer seal to maintain the integrity of the containment boundary. A photograph of the test equipment is shown in Figure 1.

\section{DISCUSSION OF COMPRESSION RANGES}

When the O-ring is assembled into the fixture and the inner disc of the fixture is offset by the maximum amount, a condition of minimum compression will be obtained in part of the O-ring. The minimum compression on the O-ring will have a range that depends on the specimen and fixture measurements and is found as follows.

The test fixture has dimensions according to the test plan/procedure drawings are shown in Table 1. These are calculated values and will not be inspected. The inside diameter of the O-ring fixture groove includes a $0.05-\mathrm{mm}$ run-out to the outside diameter of the inner disc. 


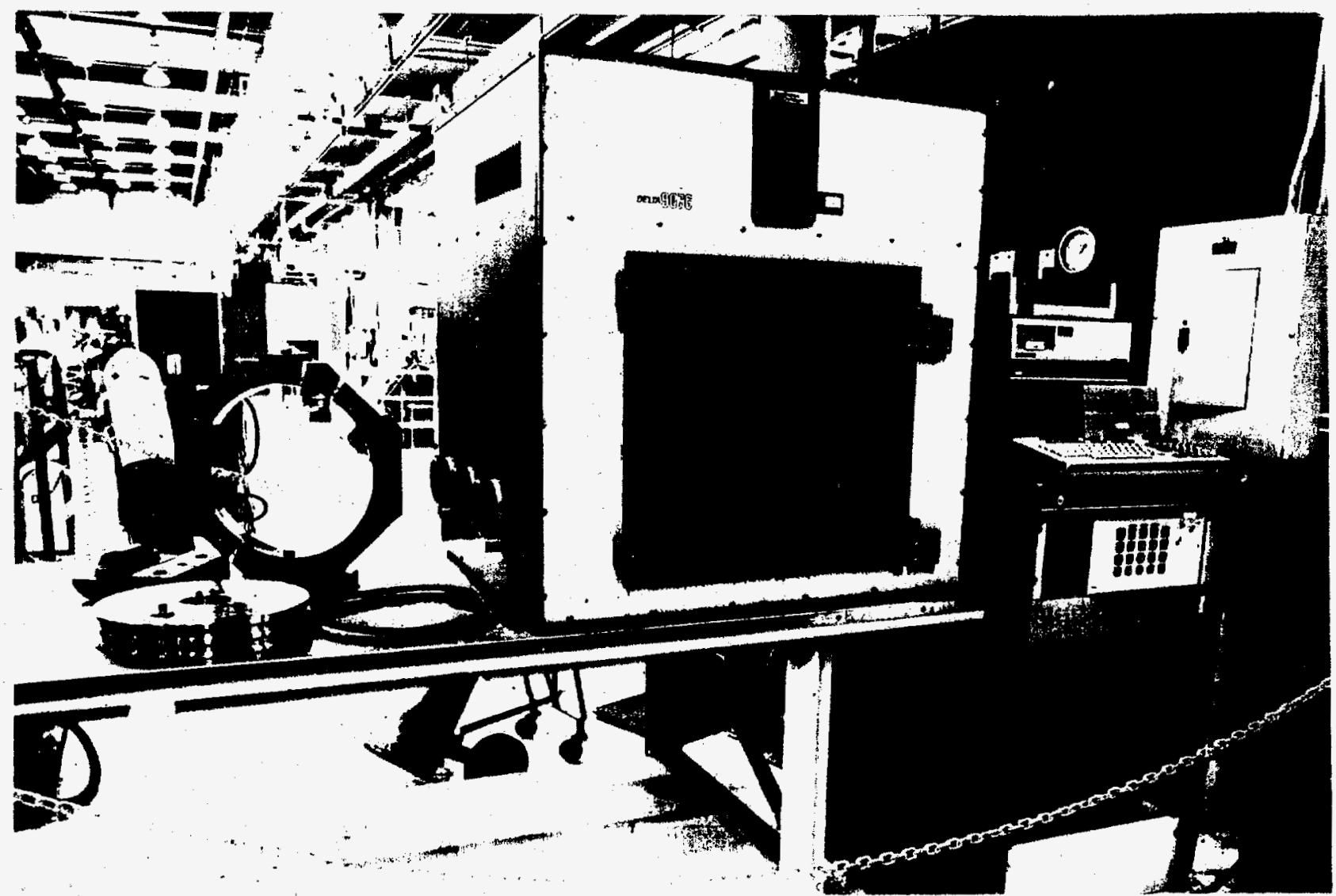

FIGURE 1. Radioisotope Thermoelectric Generator O-Ring Test Setup.

TABLE 1. Test Fixture Dimensions.

\begin{tabular}{|lcc|}
\hline \multicolumn{1}{|c}{ Feature } & Dimension (mm) & Sheet \\
\hline $\begin{array}{l}\text { Inside diameter of the outer } \\
\text { fixture frame }\end{array}$ & $323.545 \pm 0.025$ & 4 \\
$\begin{array}{l}\text { Outside diameter of the O-ring } \\
\text { fixture groove }\end{array}$ & $322.174 \pm 0.025$ & 5 \\
$\begin{array}{l}\text { Inide diameter of the O-ring } \\
\text { fixture groove }\end{array}$ & $308.762 \pm 0.025$ & 5 \\
\hline
\end{tabular}

According to the Parker $O$-Ring Handbook, Figure A4-9, the cross section of the O-ring is reduced by 1.7 percent for a stretch of 2 to 3 percent (Parker 1992). The minimum cross section at room temperature is

$$
(9.982 \mathrm{~mm}-0.178 \mathrm{~mm}) *(25.4 \mathrm{~mm}-0.432 \mathrm{~mm})=9.63 \mathrm{~mm} \text { in cross section diameter. }
$$

The centered maximum space width for the O-ring is half the difference of the minimum inside diameter (ID) of the O-ring groove from the maximum outside fixture inside diameter, or

$$
(323.545 \mathrm{~mm}-308.712 \mathrm{~mm}) / 2=7.417 \mathrm{~mm}
$$

The fixture was offset by half the difference of the maximum ID of the outer frame diameter minus the minimum outside diameter (OD) of the inner O-ring fixture groove plus half the total run out, or

$$
(323.545 \mathrm{~mm}-322.174 \mathrm{~mm}) / 2+0.025 \mathrm{~mm}=0.711 \mathrm{~mm}
$$


therefore, the maximum offset condition space for the O-ring is

$$
7.417 \mathrm{~mm}+0.711 \mathrm{~mm}=8.128 \mathrm{~mm} .
$$

The minimum offset side is

$$
7.417 \mathrm{~mm}-0.711 \mathrm{~mm}=6.706 \mathrm{~mm} \text {. }
$$

The minimum possible squeeze using O-ring cross section is

$$
(9.627 \mathrm{~mm}-8.128 \mathrm{~mm}) / 9.627 \mathrm{~mm}=15.6 \% \text {. }
$$

The maximum side compression in the test fixture is

$$
(9.627 \mathrm{~mm}-6.706 \mathrm{~mm}) / 9.627 \mathrm{~mm}=30.3 \%
$$

The minimum seal compression in the fixture is the value that results when the inner disc is offset by the maximum amount. This value demonstrates the sealing ability of the material at low compression and high temperatures. The test fixture is constructed of an outer fixture with a central hole in which a disc is located. Clearance exists between the outer fixture and inner disc such that when the disc is offset the $O$-ring is compressed more on one side than the other side. This value is known as the maximum-minimum or "max-min" compression. These dimensional values are derived from Table 1, Test Fixture Dimensions.

$\begin{array}{ll}x=\text { Minimum ID of the Outer Fixture Frame } & 323.494 \mathrm{~mm} \\ y=\text { Maximum ID of Fixture Groove } & 308.762 \mathrm{~mm} \\ z=\text { Maximum OD of Fixture Groove } & 322.224 \mathrm{~mm} \\ r=\text { Maximum Radial Run-out, between Groove OD and ID } & 000.025 \mathrm{~mm} .\end{array}$

The corresponding space available for the O-ring to occupy is, therefore

$$
\frac{(x-y)}{2}+\frac{(x-z)}{2}-r=7.976 \mathrm{~mm}
$$

The mounted O-ring cross section will be

$$
\mathrm{D}=(25.4 \mathrm{~mm}-0.432 \mathrm{~mm}) \mathrm{D}_{\mathrm{m}}
$$

where $D$ is minimum cross section as mounted, $D_{m}$ is the free-state measured cross section. The largest value from any O-ring is used. The max-min compression is, then

$$
C=\frac{(\mathrm{D}-7.976 \mathrm{~mm})}{\mathrm{D}}
$$

The smallest space for the O-ring to occupy on the high-compression side of the fixture was found above to be 0.264. The maximum overall compression in the fixture is, then

$$
C_{\max }=(D-6.706 \mathrm{~mm})
$$

The O-ring, under these conditions of minimum compression. was tested at elevated temperatures for the times listed in Table 2 below. Two $O$-rings were used in the test fixture. 
WHC-SA-2489-FP

TABLE 2. Test Time/Temperature Ranges.

\begin{tabular}{|cccc|}
\hline Test & Temperature K $\left(^{\circ} \mathrm{F}\right)$ & Time & Number of Runs \\
\hline 1 & $477(400)$ & $8 \mathrm{~h}$ & 1 \\
2 & $463(375)$ & $24 \mathrm{~h}$ & 2 \\
3 & $450(350)$ & $168 \mathrm{~h}$ & 2 \\
\hline
\end{tabular}

\section{TEST RESULTS}

A summary of the seal test results is shown in Table 3 . The seals were tested against a leakage acceptance criteria of $1 \times 10^{-7} \mathrm{~atm}-\mathrm{cc} / \mathrm{s}$, air (WHC 1989b). All seal tests were shown to be satisfactory and did not show any sign of failure through the test range.

TABLE 3. Summary of Test Results.

\begin{tabular}{|ccccccc|}
\hline Test & O-Ring & $\begin{array}{c}\text { Max-Min } \\
\text { Comp. } \\
(\%)\end{array}$ & $\begin{array}{c}\text { Max } \\
\text { Comp. } \\
(\%)\end{array}$ & $\begin{array}{c}\text { Test } \\
\text { Temp. } \\
(\mathrm{K})\end{array}$ & $\begin{array}{c}\text { Hours } \\
\text { at } \\
\text { Temp. }\end{array}$ & $\begin{array}{c}\text { Leak Rate } \\
\left(1 \times 10^{\prime} \text { atm-ce/s, }\right. \\
\text { air) or Lower }\end{array}$ \\
\hline 1 & 1 & 17.7 & 30.7 & 477 & 8 & yes \\
2 & 2 & 17.5 & 30.5 & 477 & 8 & yes \\
& 3 & 17.6 & 30.5 & 46.3 & 24 & yes \\
3 & 4 & 17.7 & 30.7 & 463 & 24 & yes \\
& 5 & 17.7 & 30.7 & 463 & 24 & yes \\
4 & 6 & 17.7 & 30.7 & 463 & 24 & yes \\
& 7 & 17.6 & 30.5 & 450 & 168 & yes \\
5 & 8 & 17.5 & 30.5 & 450 & 168 & yes \\
& 9 & 17.5 & 30.5 & 450 & 168 & yes \\
& 10 & 17.5 & 30.5 & 450 & 168 & yes \\
\hline
\end{tabular}

Seal leak-tightness also is demonstrated at the temperatures and durations shown in Table 3. Compression values ranged from as low as 17.5 percent to as high as 30.7 percent.

During the testing, minor changes in the durometer were noted, and the O-rings took a compression set. These material changes seemed to have little impact on the ability to maintain seal integrity through the range of temperature and time tested. Table 4 is a summary of compiled O-ring information from the test data.

TABLE 4. O-Ring Material Measurement Data.

\begin{tabular}{|c|c|c|c|c|c|c|c|c|c|c|c|c|}
\hline \multirow[t]{2}{*}{ O-Ring } & \multirow[t]{2}{*}{ Test } & \multirow[t]{2}{*}{$\begin{array}{l}\text { Measurement } \\
\text { Sequence }\end{array}$} & \multicolumn{4}{|c|}{$\begin{array}{l}\text { Cross-Sectional Radial Dimension } \\
\text { (mm) }\end{array}$} & \multicolumn{3}{|c|}{$\begin{array}{c}\text { Cross-Sectional Axial Dimension } \\
\text { (mm) }\end{array}$} & \multirow{2}{*}{$\begin{array}{c}\text { Inside } \\
\text { Diameter } \\
(\mathrm{mm})\end{array}$} & \multirow{2}{*}{\multicolumn{2}{|c|}{$\begin{array}{c}\text { Hardness } \\
\text { Shore A } \\
\text { (Durometer) }\end{array}$}} \\
\hline & & & $45^{\circ}$ & $135^{\circ}$ & $225^{\circ}$ & $315^{\circ}$ & $45^{\circ} \quad 135^{\circ}$ & $225^{\circ}$ & $315^{\circ}$ & & & \\
\hline 1 & 1 & Before & 9.855 & 9.830 & 9.830 & 9.830 & $9.906 \quad 9.906$ & 9.881 & 9.881 & 299.822 & 75 & 75 \\
\hline 1 & 1 & After & 8.280 & 7.849 & 7.645 & 7.899 & $10.439 \quad 10.973$ & 11.227 & 10.592 & 304.000 & 70 & 70 \\
\hline 2 & 1 & Before & 9.804 & 9.830 & 9.830 & 9.830 & $9.804 \quad 9.830$ & 9.830 & 9.830 & 299.822 & 75 & 75 \\
\hline 2 & 1 & Afler & 7.950 & 8.509 & 8.357 & 7.772 & $10.973 \quad 10.490$ & 10.947 & 10.922 & 304.241 & 68 & 68 \\
\hline 3 & 2 & Before & 9.804 & 9.830 & 9.830 & 9.830 & $9.804 \quad 9.830$ & 9.830 & 9.830 & 299.796 & 75 & 76 \\
\hline 3 & 2 & After & 8.280 & 7.645 & 8.153 & 8.509 & $10.979 \quad 11.201$ & 10.846 & 10.693 & 304.622 & 70 & 78 \\
\hline
\end{tabular}


TABLE 4. O-Ring Material Measurement Data.

\begin{tabular}{|c|c|c|c|c|c|c|c|c|c|c|c|c|c|}
\hline \multirow[t]{2}{*}{ O-Ring } & \multirow[t]{2}{*}{ Test } & \multirow[t]{2}{*}{$\begin{array}{l}\text { Measurement } \\
\text { Sequence }\end{array}$} & \multicolumn{3}{|c|}{$\begin{array}{c}\text { Cross-Sectional Radial } \\
\text { (mm) }\end{array}$} & \multirow[t]{2}{*}{$\frac{\text { Dimension }}{315^{\circ}}$} & \multicolumn{4}{|c|}{$\begin{array}{c}\text { Cross-Sectional Axial Dimension } \\
(\mathrm{mm})\end{array}$} & \multirow{2}{*}{$\begin{array}{c}\text { Inside } \\
\text { Diameter } \\
(\mathrm{mm})\end{array}$} & \multirow{2}{*}{\multicolumn{2}{|c|}{$\begin{array}{c}\text { Hardness } \\
\text { Shore A } \\
\text { (Duromeler) }\end{array}$}} \\
\hline & & & $45^{\circ}$ & $135^{\circ}$ & $225^{\circ}$ & & $45^{\circ}$ & $135^{\circ}$ & $225^{\circ}$ & $315^{\circ}$ & & & \\
\hline 4 & 2 & Before & 9.855 & 9.830 & 9.830 & 9.830 & 9.855 & 9.830 & 9.855 & 9.830 & 300.126 & 75 & 75 \\
\hline 4 & 2 & Afler & 8.306 & 7.874 & 7.696 & 8.306 & 10.541 & 11.278 & 10.947 & 10.262 & 304.775 & 70 & 73 \\
\hline 5 & 3 & Before & 9.830 & 9.830 & 9.855 & 9.830 & 9.830 & 9.881 & 9.830 & 9.830 & 299.822 & 75 & 75 \\
\hline 5 & 3 & Afler & 8.255 & 7.925 & 7.645 & 8.230 & 10.516 & 10.922 & 11.125 & 10.643 & 304.419 & 71 & 72 \\
\hline 6 & 3 & Before & 9.855 & 9.855 & 9.855 & 9.855 & 9.855 & 9.855 & 9.855 & 9.855 & 299.898 & 75 & 75 \\
\hline 6 & 3 & After & 7.798 & 7.696 & 8.331 & 8.280 & 11.201 & 11.125 & 10.465 & 10.617 & 303.403 & 73 & 73 \\
\hline 7 & 4 & Before & 9.830 & 9.830 & 9.830 & 9.830 & 9.830 & 9.830 & 9.830 & 9.830 & 29.9 .771 & 75 & 75 \\
\hline 7 & 4 & After & 8.331 & 8.103 & 7.518 & 7.595 & 10.770 & 10.897 & 11.074 & 11.659 & 304.000 & 72 & 74 \\
\hline 8 & 4 & Before & 9.830 & 9.830 & 9.830 & 9.830 & 9.830 & 9.855 & 9.830 & 9.830 & 299.796 & 75 & 74 \\
\hline 8 & 4 & After & 8.280 & 7.976 & 7.417 & 7.950 & 10.947 & 11.236 & 11.532 & 11.684 & 307.848 & 72 & 72 \\
\hline 9 & 5 & Before & 9.830 & 9.830 & 9.830 & 9.830 & 9.830 & 9.830 & 9.830 & 9.830 & 299.898 & 75 & 75 \\
\hline 9 & 5 & Afler & 8.357 & 8.026 & 7.417 & 7.950 & 10.541 & 11.024 & 11.049 & 10.338 & 305.054 & 76 & 73 \\
\hline 10 & 5 & Before & 9.830 & 9.830 & 9.830 & 9.830 & 9.830 & 9.830 & 9.830 & 9.830 & 299.822 & 75 & 75 \\
\hline 10 & 5 & After & 7.849 & 7.341 & 7.823 & 8.306 & 11.049 & 10.312 & 10.668 & 10.439 & 304.978 & 75 & 75 \\
\hline
\end{tabular}

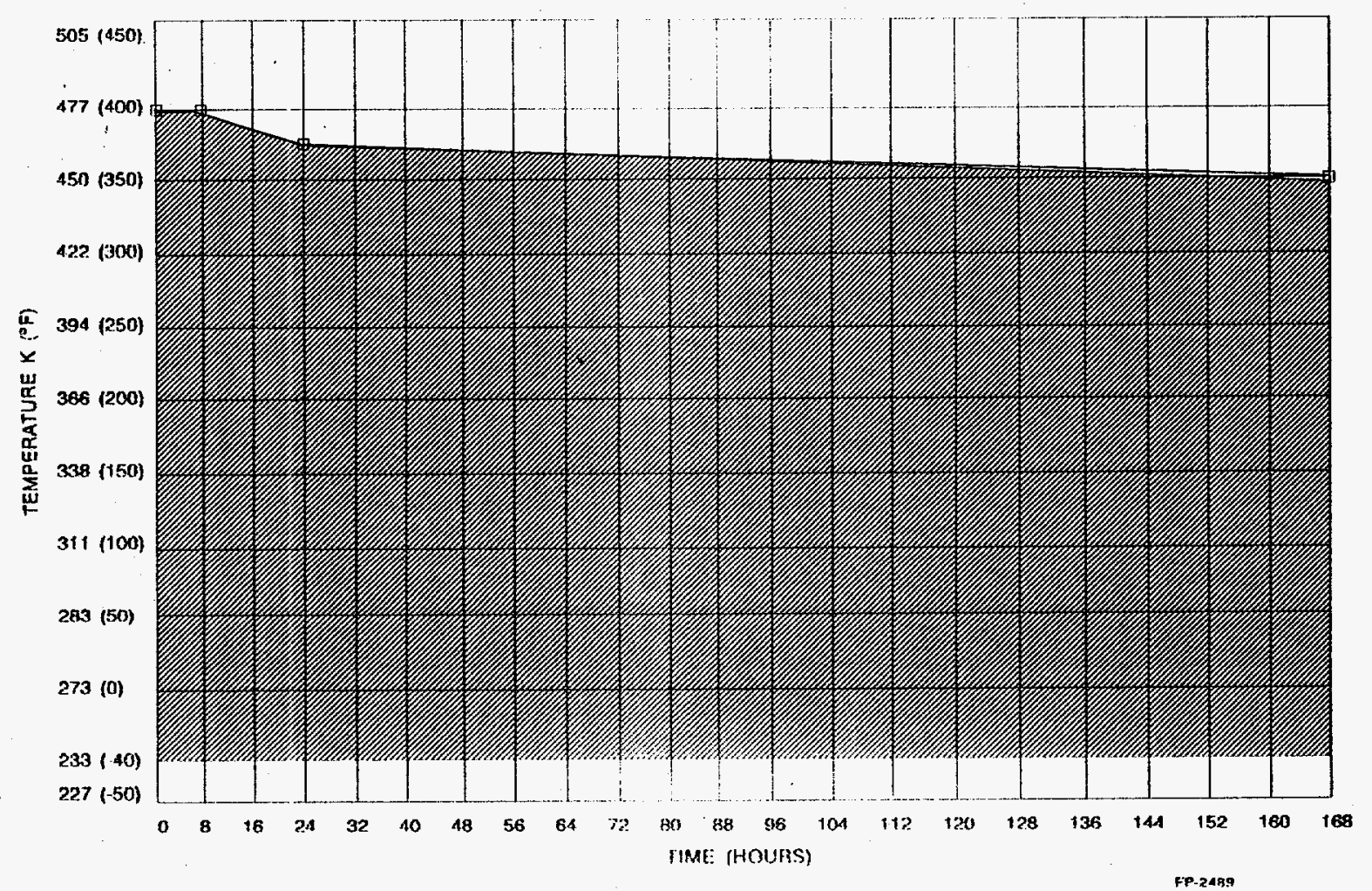

FIGURE 2. Buytl O-Ring Operating Temperature Envelope. 


\section{CONCLUSIONS}

The butyl O-ring materfal bas shown to be satisfactory for use in the RTG Transportation System as long as the temperatures in the seal area are within the operating temperature envelope shown in Figure 2 . Seal temperature requirements performed by analysis define the temperatures to be within that operating temperature envelope.

\section{Acknowledgments}

This work was performed by the Westinghouse Hanford Company under contract to the United States Department of Energy (DE-AC06-87RL-10930).

\section{References}

10 CFR 71 (1994) "Packaging and Transportation of Radioactive Materials," Subparts E and F, Code of Federal Regulations, as amended.

Parker (1992) Parker O-Ring Handbook, GL-9/92, Parker Hannifin Corporation, Cleveland, Ohio.

WHC (1989a) NuPAC Trupact-II Safery Analysis Report, Appendix 2.10.7, "TruPact-II Seal/Closure

Performance Tests" and Drawing SK-835, "O-Ring Test Fixture Assembly, "Westinghouse Hanford Company, Richland, Washington.

WHC (1989b) Nondesmuctive Examination Procedures, WHC-CM-4-38, Westinghouse Hanford Company, Richland, Washington.'

WHC (1993) Radioisotope Thermoelectric Generator. Tramsportation System Packaging O-Ring Material Thermal Validation Test Plan/Procedure, WHC-SD-RTG-TP-006, Rev. 1, Westinghouse Hanford Company, Richland, Washington.

WHC (1994) Radioisotope Thermoelectric Generator Tramsportation System Packaging O-Ring Material Thermal Validation Test Report, WHC-SD-RTG-TRP-001, Rev.1, Westinghouse Hanford Company, Richland, Washington. 


\section{DISTRIBUTION}

Number of copies

OFFSITE

1

Institute for Space and Nuclear Power Studies

College of Enineering

The University of New Mexico

Albuquerque, NM 87131-1341

\section{ONSITE}

4

Westinghouse Hanford Company

H. E. Adkins

N $1-25$

Central Files

L8-04

Office of Scientific and

Technical Information

A3-36

Distr-1 